\title{
Estimation of the Changes in Hematological Standards of Albino Rabbits Treated with Different Concentrations for Alcoholic Extract of Cyperus rotundus (Nutsedge) and Rosmarinus officinalis (Rosemary)
}

\author{
Sarmad Abdul Razzaq Abood Alsaadi* \\ Department of Basic Sciences, College of Dentistry, University of Kirkuk, Iraq \\ *Corresponding author
}

\section{Keywords}

Alcoholic Extract,

Nutsedge,

Rosemary,

Hematological

Standards,

Albino

Rabbits.

\begin{tabular}{l}
\hline Article Info \\
\hline Accepted: \\
25 June 2016 \\
Available Online: \\
10 July 2016
\end{tabular}

A B S T R A C T

This study aimed to test the physiological effectiveness of alcoholic extract to Cyperus rotundus (Nutsedge) tubers and Rosmarinus officinalis (Rosemary) leaves in some of the hematological laboratory tests: Total Red Blood Cells count (T.R.B.Cs), Estimation of the blood hemoglobin level (Hb Estimation), Packed Cell Volume (P.C.V.), Chromatography Index of Hemoglobin (C.I.), Mean Corpuscular Volume (M.C.V.), Mean Corpuscular Hemoglobin (M.C.H.) and Mean Corpuscular hemoglobin concentration (M.C.H.C.) in the blood sample in albino rabbits. The rabbit was divided into three groups, depending on the three supposed concentrations that derived from each individual extract, respectively: the first group (100 mg / kg), the second group (250 mg / kg) and the third group (500 $\mathrm{mg} / \mathrm{kg})$. Rabbits had been administrated orally by $(0.1 \mathrm{ml})$ of each extract in different three concentrations, The results indicated the significantly increasing at averages of $(\mathrm{Hb})$ and (P.C.V.) tests for the (Rosemary 500) group and (Nutsedge 500) group for both extracts in comparison with residue experimental groups, in addition to high values of (T.R.B.Cs) at (Nutsedge 500) group when compared to control group values. The results of (M.C.V.), (M.C.H.) and (M.C.H.C.) showed a significant elevation in the averages of the third group that treated with $(500 \mathrm{mg} /$ $\mathrm{kg}$ ) alcoholic extract of Nutsedge tubers in measuring with the control group, while the significant superiority was remarkable in the averages of (M.C.H.) and (M.C.H.C.) of the alcoholic extract of Rosemary leaves $(250 \mathrm{mg} / \mathrm{kg}$ ). The results of (T.R.B.Cs) and (C.I.) tests hadn't shown any significant variation between all present study. The conclusion of this study is the affirmative impact of Cyperus rotundus (Nutsedge) tubers and Rosmarinus officinalis (Rosemary) leaves alcoholic extract in improving of some blood traits in the rabbits that treated with these extracts.

\section{Introduction}

Since ancient times Cyperus rotundus (Nutsedge) and Rosmarinus officinalis (Rosemary) have been considered a healthpromoting beverage.
In recent years, scientists throughout the world have investigated the potential benefits of Nutsedge and Rosemary (Albayati, 2011). They have merit in many aspects of life, and the most common use of 
herbs for medicinal purposes like treatment of acute and chronic diseases, and on the other hand improving of the whole body vital organs activities (Kamboj, 2000). The Nutsedge and Rosemary occupies ranked first among the medicinal plants that will improve greatly the turbulent cases of the cardiovascular system and biochemical features of the blood and maintenance metabolic health (Jahan et al., 2012).

The biological effects of the Nutsedge and Rosemary attributed to the active compounds in their chemical composition of that make them at the forefront of medicinal antioxidant plants in treatment of competent circulatory system disorders and improved of blood parameters in the healthy and the sick body (Iris et al., 2011).

Nutsedge tubers and Rosemary leaves are shared in some of principles bioactive ingredients in their chemical composition. The constituents included in Nut sedge tubers are: Alkaloids, Polyphenols, Betacarotene, Catechin, Pectin, Saccharides, Starch, Glucose, D-fructose and nonreducing sugars, Flavonoids (Rutin, Vitexin glycosides, Kaempferol, Quercetin), essential fatty oils (Glycerol, Linolenic, Linoleic, Oleic, Myristic and Stearic acid, Amino acids, Amines (Phenyletylamine, Tyramine, Omethoxyphenethylamine), Tannins (condensed Proanthocyanidins), Oligomeric Procyanidins, Saponins, Cardiac glycosides, many valuable minerals (Calcium, Sodium, Cobalt, Iron, Manganese, Zinc, Potassium and Magnesium) and vitamin C (Oladunni et al., 2011).

The chemical composition of Rosemary leaves is like: Many Polyphenols as (Catechins, Flavonoids, Oligomeric Procyanidines OPC), Terpenoids, Vitexin, glycosides and Cyanogenetic glycosides, Tannins, Saponins, Cafes and Chlorogenic acids, important Amino acids such as: (5-
Nethylglutamine, Glutamic acid, Tryptophan, Glycine, Serine, Aspartic acid, Tyrosine, Valine, Leucine, Lsoleucine, Threonine, Arginine, Lysine. Carbohydrates such as: (Cellulose, Pectins, Glucose, Fructose, Sucrose; Lipids as Linoleic and Linolenic acids, some vital Vitamins like (Vitamin A, B1, B2, B3, B6, B12, C, E, Fe, $\mathrm{Cu}, \mathrm{F}, \mathrm{K}, \mathrm{P}, \mathrm{U}$ ) and Minerals like (Calcium, Copper, Manganese, Phosphorus, Selenium and Zinc) (Kalveniene et al., 2007). Oxidative damage in erythrocytes as a result of high polyunsaturated fatty acid content in their membranes and high concentration of oxygen and hemoglobin high affinity binding free radicals, the latter being a potentially powerful promoter of oxidative processes (Nagababu et al., 2016). The free radicals easily react with red blood cell components, including proteins and lipids leading to their oxidative modifications, Damages of erythrocytes component structure lead to changes in their functions, which in consequence disturb cell metabolism and reformation (Mohanty et al., 2014).

The oxidant reactions with hemoglobin destabilize will produce the heme and globin structure and release free iron ions that play a significant role in the generation of free radicals (Vasudevan and Sreekumari, 2007). The deleterious consequences of the above mentioned actions have stimulated studies on the mechanisms of action of biologically relevant natural antioxidants such as polyphenolic compounds (Mot et al., 2015). One of such potential health promoting beverages is Nutsedge and Rosemary, whose components, mainly catechins and catechin derivatives, have antioxidant properties (Kandikattu et al., 2015; Sancheti and Goyal, 2006). Moreover, an important role of Nutsedge and Rosemary in the improvement of the defense system against oxidative free radicals was evidenced by reference to different tissues that responsible 
for the formation of erythrocytes an example: the liver, bone marrow, spleen and the blood cells themselves (Yazdanparast and Ardestani, 2007; del Bano et.al. 2003).

\section{Materials and Methods}

\section{Animals used in the study}

All the blood tests have been conducted in laboratory albino rabbit, ryctolagus cuniculus, which were bred in the specialist laboratory research of the Department of Biology / Faculty of Science / University of Kirkuk; and the age was 3 months at the beginning of dosage, rabbits had been distributed randomly in predisposing cages and had given water and the bush, and for all study groups standard conditions have been created.

\section{Preparation of the extracts}

For performing of extracts, weighed 40 grams each of powdered Nutsedge tubers and Rosemary leaves (was crushed using an electric grinding blender) and put in a thimble and then transferred to a soxhlet apparatus and then added $(400 \mathrm{ml})$ of ethanol $70 \%$ and the device is turned on for a period (10-12 hours) (Harborn, 1984), then after completion of the process of extraction, solvent was evaporated by placing it in the Rotary Evaporating system at temperature in $55{ }^{\circ} \mathrm{C}$. The alcoholic extract was pulled out from 40 grams of the powder plant by subtracting the weight of empty beaker from its weight with extract, then the extract had dissolved in a certain volume of distilled water and use the extract in the study upon the completion of reclaimed.

\section{Experimental design}

28 albino laboratory rabbits have been divided into 7 groups equally; one of which was an untreated control group that administrated with Distal water (1 ml/rabbit) daily, then the remaining six groups were treated by extracts with as followed:

( $\mathrm{R}$ 100) group: It's 4 rabbits have been dosed $(1 \mathrm{ml} / \mathrm{rabbit})$ orally with $(100 \mathrm{mg} / \mathrm{kg})$ alcoholic extract of Rosemary leaves.

(R 250) group: It's 4 rabbits have been dosed (1 $\mathrm{ml} / \mathrm{rabbit})$ orally with $(250 \mathrm{mg} / \mathrm{kg})$ alcoholic extract of Rosemary leaves.

(R 500) group: It's 4 rabbits have been dosed (1 $\mathrm{ml} / \mathrm{rabbit})$ orally with $(500 \mathrm{mg} / \mathrm{kg})$ alcoholic extract of Rosemary leaves.

(N 100) group: It's 4 rabbits have been dosed $(1 \mathrm{ml} / \mathrm{rabbit})$ orally with $(100 \mathrm{mg} / \mathrm{kg})$ alcoholic extract of Nutsedge.

(N 250) group: It's 4 rabbits have been dosed $(1 \mathrm{ml} / \mathrm{rabbit})$ orally with $(250 \mathrm{mg} / \mathrm{kg})$ alcoholic extract of Nutsedge.

(N 500) group: It's 4 rabbits have been dosed $(1 \mathrm{ml} / \mathrm{rabbit})$ orally with $(500 \mathrm{mg} / \mathrm{kg})$ alcoholic extract of Nutsedge.

The total experiment duration was 3 months, started with beginning of dosing at 3 months age of rabbits and ended at 6 month age.

\section{Blood collection}

The blood samples have been collected at the end of the study (at 6 months age of rabbits) by Ear vein by using of sterile syringe, The Quantity of blood was withdrawn $(1-2 \mathrm{ml})$ for testing by current study.

Detection of active compounds in the alcoholic extract of Nutsedge and Rosemary

In order to detect the active chemical compounds in both plant extracts in the 
current study; Common biochemical reagents have been performed to Nutsedge and Rosemary after extracting them as indicated in the table (1).

\section{Statistical Analysis}

Data are expressed as means \pm standard error. ANOVA with one tailed $t$ test were used for statistical evaluation of significant differences in means between the experimental groups, so differences were considered significant when $(\mathrm{P}<0.05)$ (Steel and Torrie, 1986).

\section{Results and Discussion}

\section{Results of alcoholic extract of an alcoholic extract of Cyperus rotundus and Rosmarinus officinalis (Rosemary)}

Data gathered at the table (2) were showing a significant effect $(\mathrm{p}<0.05)$ of the an alcoholic extract of Cyperus rotundus (Nutsedge) at the (A $500 \mathrm{mg} / \mathrm{kg}$ ) group averages of compared with those in the control group except in the (C.I.) test, where that there is no significant increase in its rates of experimental groups, and regarding to the (T.R.B.Cs) test at (A $500 \mathrm{mg} / \mathrm{kg}$ ) group, a significant increasing $(\mathrm{p}<0.05)$ was observed at its values when compared to control. So (Hb and P.C.V.) averages at (A $250 \mathrm{mg} / \mathrm{kg}$ ) group showed notable excess $(\mathrm{p}<0.05)$ in comparison with control values. On the other hand, no significant difference was found between the all hematological tests in $(100 \mathrm{mg} / \mathrm{kg})$ groups and those in control.

The data in table (3) show the most significant increasing $(\mathrm{p}<0.05)$ in the averages of (R500) group of all hematological tests excepted in (T.R.B.Cs and C.I.) which no significant variation had seen among their study groups. The values of (250 mg / kg) group were increased, most markedly at ( $\mathrm{Hb}$ and M.C.H.C.) tests. Moreover, there were no statistically significant changes in the level of the remaining parameters. While there is no significant effect for (R100 mg / kg) group of any experimental parameters excepting (Hb and M.C.H.C.) which have an obvious elevation in their averages in comparison with the control

group.

Discusses the results of Cyperus rotundus (Nutsedge) and Rosmarinus officinalis (Rosemary) alcoholic extract

Approximately, the alcoholic extraction of Nutsedge and Rosemary are involved in their composition the same chemical active ingredients and this was demonstrated by the results of matching the overall detection of active substances in (Table 1) taking into account different proportions of each of them making it easier for researchers give the proper interpretation of the results of such studies. With exception of (C.I.), the results in (table 2 and 3) were showing an improving at whole hematological parameter averages, particularly in (A $500 \mathrm{mg} / \mathrm{kg}$ ) and (R $500 \mathrm{mg} / \mathrm{kg}$ ) which they represent the highest concentration among the experimental groups, inconsistent with (Ahmad et al., 2012) that long-term drinking of Nutsedgeled to an increasing in the erythrocyte count in albino rabbits and moreover, protects the structure of the erythrocyte membrane from the oxidative damages of free radicals in the blood, also another study; Slipa et al., (2014) has proved that the lyophilised extract of Cyperus rotundus administration prevented hemoglobin destruction as a result to ethanolic intoxication in diabetic rats, Additionally, the present mentioned results agree with the results described by Necib et al., (2015) that Cyperus rotundus catechins 
show significant increase in erythrocyte Malondialdehyde (MDA) level in the rabbits and act in the protection of erythrocytes against oxidative stress. At the regarding of Rosemary, the ingredients biological activity and impacts of haematological standards, Consistent with the results that indicated by Karimi et al., (2005) which proved to be the essential oil that extracted from the
Rosemary leaves were in vitro effects in rats led to a significant amelioration in the blood constants and prevent hemolysis, so rosemary has the ability to scavenge peroxyl radicals. Thus, the possibility that rosemary exerts its cytoprotective effects at the membrane level, as a chain-breaking antioxidant, should also be considered (Rezaie et al., 2012).

Table.1 Results of the biochemical active reagents at Alcoholic

Extract to Nutsedge and Rosemary

\begin{tabular}{|c|c|c|c|c|c|c|}
\hline $\begin{array}{l}\text { Reagents } \\
\text { Plannt } \\
\text { Extrakts }\end{array}$ & Tannins & Saponins & Resins & Alkaloids & Flavons & Glycosides \\
\hline Nutsedge & $\begin{array}{l}\text { Lead acetate (+ve) } \\
\text { Ferric chloride (+ve) }\end{array}$ & $(+\mathrm{ve})$ & $(+v e)$ & $(+\mathrm{ve})$ & $(+\mathrm{ve})$ & $(+\mathrm{ve})$ \\
\hline Rosemary & $\begin{array}{l}\text { Lead acetate (+ve) } \\
\text { Ferric chloride (+ve) }\end{array}$ & $(+\mathrm{ve})$ & (+ve) & $(+\mathrm{ve})$ & $(+\mathrm{ve})$ & $(+\mathrm{ve})$ \\
\hline
\end{tabular}

Table.2 Showing the physiological effects of an alcoholic extract of Nutsedge (Cyperus rotundus) on some hematological values in adult Albino rabbits:

\begin{tabular}{|c|c|c|c|c|c|c|c|}
\hline Tests & $\begin{array}{c}\text { Total RBCs } \\
\left(\div 10^{3} / \mu \mathrm{l}\right)\end{array}$ & $\begin{array}{c}\mathrm{Hb} \\
(\mathrm{g} / \mathrm{d} \mathrm{l})\end{array}$ & $\begin{array}{l}\text { P.C.V. } \\
(\%)\end{array}$ & C.I. & $\begin{array}{l}\text { M.C.V. } \\
\left.\left(\mu \mathrm{m}^{3}\right]\right)\end{array}$ & $\begin{array}{l}\text { M.C.H. } \\
\text { (pg) }\end{array}$ & M.C.H.C. \\
\hline Control group & $\begin{array}{l}9.37 \pm 0.41 \\
\text { a }\end{array}$ & $\begin{array}{c}12.55 \pm 0.42 \\
\text { a }\end{array}$ & $\begin{array}{c}54.75 \pm 1.43 \\
\text { a }\end{array}$ & $\begin{array}{c}0.46 \pm 0.03 \\
\text { a }\end{array}$ & $\begin{array}{c}58.87 \pm 0.57 \\
\text { a }\end{array}$ & $\begin{array}{c}13.39 \pm 0.43 \\
\text { a }\end{array}$ & $\begin{array}{c}22.92 \pm 0.42 \\
\text { a }\end{array}$ \\
\hline $\begin{array}{c}\text { N } 100 \mathrm{mg} / \mathrm{kg} \\
\text { group }\end{array}$ & $\begin{array}{c}9.79 \pm 0.67 \\
\text { ab }\end{array}$ & $\begin{array}{c}13.79 \pm 0.74 \\
a b\end{array}$ & $\begin{array}{c}57.25 \pm 1.28 \\
\text { a }\end{array}$ & $\begin{array}{c}0.47 \pm 0.02 \\
\text { a }\end{array}$ & $\begin{array}{c}59.02 \pm 0.75 \\
\text { a }\end{array}$ & $\begin{array}{c}14.21 \pm 0.55 \\
\text { ab }\end{array}$ & $\begin{array}{c}24.08 \pm 0.56 \\
\text { ab }\end{array}$ \\
\hline $\begin{array}{c}\text { N } 250 \mathrm{mg} / \mathrm{kg} \\
\text { group }\end{array}$ & $\begin{array}{c}10.83 \pm 0.69 \\
\text { ab }\end{array}$ & $\begin{array}{c}15.88 \pm 0.54 \\
b\end{array}$ & $\begin{array}{c}64.5 \pm 1.17 \\
b\end{array}$ & $\begin{array}{c}0.49 \pm 0.03 \\
\text { a }\end{array}$ & $\begin{array}{c}59.72 \pm 0.51 \\
\text { a }\end{array}$ & $\begin{array}{c}14.7 \pm 0.61 \\
\text { ab }\end{array}$ & $\begin{array}{c}24.82 \pm 0.8 \\
\text { ab }\end{array}$ \\
\hline $\begin{array}{c}\text { N } 500 \text { mg / kg } \\
\text { group }\end{array}$ & $\begin{array}{c}11.32 \pm 0.43 \\
b\end{array}$ & $\begin{array}{c}18.79 \pm 0.71 \\
c\end{array}$ & $\begin{array}{c}70.25 \pm 1.21 \\
\text { c }\end{array}$ & $\begin{array}{c}0.55 \pm 0.05 \\
\text { a }\end{array}$ & $\begin{array}{c}62.16 \pm 0.54 \\
\text { b }\end{array}$ & $\begin{array}{c}15.58 \pm 0.52 \\
b\end{array}$ & $\begin{array}{c}25.62 \pm 0.73 \\
\text { b }\end{array}$ \\
\hline
\end{tabular}

- Values are means \pm standard error.

- $a, b, c$, means in arrow for giving tests with different letters differs significantly $(\mathrm{p}<0.05)$. 
Table.3 Showing the physiological effects of alcoholic extract of Rosmarinus officinalis (Rosemary) on some hematological values in adult Albino rabbits:

\begin{tabular}{|c|c|c|c|c|c|c|c|}
\hline Tests & $\begin{array}{r}\text { Total RBCs } \\
\left(* 10^{3} / \mu \mathrm{l}\right)\end{array}$ & $\begin{array}{c}\text { Hb } \\
(\mathrm{g} / \mathrm{d} \text { l) }\end{array}$ & $\begin{array}{l}\text { P.C.V. } \\
(\%)\end{array}$ & C.I. & $\begin{array}{l}\text { M.C.V. } \\
\left(\mu \mathrm{m}^{3}\right)\end{array}$ & $\begin{array}{l}\text { M.C.H. } \\
\text { (pg) }\end{array}$ & $\begin{array}{l}\text { M.C.H.C. } \\
(\mathrm{g} / \mathrm{dl})\end{array}$ \\
\hline Control group & $\begin{array}{c}9.37 \pm 0.41 \\
\text { a }\end{array}$ & $\begin{array}{c}12.55 \pm 0.42 \\
\mathrm{a}\end{array}$ & $\begin{array}{c}52.75 \pm 1.13 \\
\text { a }\end{array}$ & $\begin{array}{c}0.46 \pm 0.03 \\
\text { a }\end{array}$ & $\begin{array}{c}56.29 \pm 0.77 \\
\text { a }\end{array}$ & $\begin{array}{c}13.39 \pm 0.76 \\
\text { a }\end{array}$ & $\begin{array}{c}22.92 \pm 0.57 \\
\text { a }\end{array}$ \\
\hline $\begin{array}{l}\text { R } 100 \mathrm{mg} / \mathrm{kg} \\
\text { group }\end{array}$ & $\begin{array}{c}9.71 \pm 0.89 \\
\text { a }\end{array}$ & $\begin{array}{c}15.16 \pm 0.51 \\
\text { b }\end{array}$ & $\begin{array}{c}57.72 \pm 1.09 \\
\text { a }\end{array}$ & $\begin{array}{c}0.53 \pm 0.04 \\
\text { a }\end{array}$ & $\begin{array}{c}59.44 \pm 0.85 \\
\text { ab }\end{array}$ & $\begin{array}{c}15.61 \pm 0.68 \\
\mathrm{ab}\end{array}$ & $\begin{array}{c}26.26 \pm 0.76 \\
\text { b }\end{array}$ \\
\hline $\begin{array}{l}\text { R } 250 \mathrm{mg} / \mathrm{kg} \\
\text { group }\end{array}$ & $\begin{array}{c}10.16 \pm 0.68 \\
a\end{array}$ & $\begin{array}{c}15.15 \pm 0.44 \\
\text { b }\end{array}$ & $\begin{array}{c}59 \pm 1.02 \\
\text { a }\end{array}$ & $\begin{array}{c}0.52 \pm 0.04 \\
\text { a }\end{array}$ & $\begin{array}{c}58.07 \pm 0.49 \\
\text { a }\end{array}$ & $\begin{array}{c}14.91 \pm 0.83 \\
\text { ab }\end{array}$ & $\begin{array}{c}25.67 \pm 0.55 \\
\text { b }\end{array}$ \\
\hline $\begin{array}{c}\text { R } 500 \mathrm{mg} / \mathrm{kg} \\
\text { group }\end{array}$ & $\begin{array}{c}10.53 \pm 0.75 \\
\text { a }\end{array}$ & $\begin{array}{c}17.94 \pm 0.68 \\
\text { c }\end{array}$ & $\begin{array}{c}63.8 \pm 1.06 \\
b\end{array}$ & $\begin{array}{c}0.56 \pm 0.05 \\
\text { a }\end{array}$ & $\begin{array}{c}60.58 \pm 0.6 \\
b\end{array}$ & $\begin{array}{c}17.03 \pm 0.77 \\
\text { b }\end{array}$ & $\begin{array}{c}28.11 \pm 1.13 \\
b\end{array}$ \\
\hline
\end{tabular}

- Values are means \pm standard error.

- A, b, c, means in arrow for giving tests with different letters differs significantly $(\mathrm{p}<0.05)$.

The rosemary plant contains pharmacologically active polyphenols as: catechine, epicatechine, flavonoids and Oligomeric Procyanidines, thus; these potent antioxidants can inhibit the formation of glycated hemoglobin by lowering the levels of lipid peroxides (Afonso et al., 2013). Rosemary extract is a natural potent lipophilic antioxidant, which might be help in reducing oxidant levels in the blood cells and prohibiting of the oxidative damages at the erythroblasts in the bone marrow (Munne-Bosch and Alegre, 2001). As well as the presence of Folic acid, Iron, vitamin C and Copper in the chemical composition of Rosemary and Nutsedge is a key factor in the composition of hemoglobin molecule and integration of the growth of red blood cells (Janina et al., 2007). The Prestigious increasing in the values in the table (2 and 3) can be explained by the installation of Nutsedge and Rosemary on Thiamine (B1), Niacin (B3), Riboflavins (B12), Ascorbic acids (vitamin C), (vitamin B6), Tryptophan and folic acid that are the main factors in the growth of the body and the maturation of red blood cells and formation of their DNA (Kumar et al., 2014).

This was confirmed by the results of Vikulov et al., (2001) Which provided that the vitamins mentioned above cause an increment of ATPase activities in erythrocyte membrane and can improve the functions of erythrocytes, where the lack of any of these vitamins in the body may lead to imbalance in the formation process of red blood cells and acute decreasing in haemoglobin molecule then result of anemia (Henry, 2004), as well as is one of the most important compounds found in the composition of the Nutsedge tubers and Rosemary leaves which enters effectively and directly in the process of formation of red blood cells (erythropoiesis) in the rabbits bone marrow (Sak, 2014).

For introduce an interpretation closer to the reality of the results obtained from the study, depending on the active compounds in the Nutsedge tubers and Rosemary leaves; Arginine, Glutamic and Aspartic acid 
produced an initial increase in hemoglobin level in the blood, so Threonine and Glutamic acid are an important amino acids that well contributes to the formation haemoglobin molecule and in the same time their dramatically diminishing and deprivation will lead to impairs of erythropoiesis and decreasing of Erythropoietin responsive cells in vitro (Musiychuk et al., 2013). Leucine and Isoleucine are abundant in hemoglobin $27 \%$ and would be expected to give a maximal response when added to the diet of rabbits daily for 8 weeks (Neuwirt and Ponka, 1977). The cysteine does give a substantial response to erythrocytes regeneration and elevate the hemoglobin level above the normal baseline (Calkins et al., 2016).

In conclusion, the present study concluded that the gradually increasing in concentration of alcoholic extraction of Cyperus rotundus (Nutsedge) and Rosmarinus officinalis (Rosemary) has led to an increase and improvement in the hematological standards that approved in the current study.

\section{References}

Afonso, M.S., Silva, A., Carvalho, E., Rivelli, D., Barros, S., Rogero, M., Lottenberg, A., Torres, R. and Mancini-Filho, J. 2013. Phenolic compounds from Rosemary (Rosmarinus officinalis L.) attenuate oxidative stress and reduce blood cholesterol concentrations in dietinduced hypercholesterolemic rats. Nutri. Metabolism, 10: 19.

Ahmad, M., Mahayrookh, Mehjabeen, Bin rehman. A. and Jahan. N. 2012. Analgesic, antimicrobial and cytotoxic effect of Cyperus rotundus ethanol extract. Pakistan J. Pharmacol., 29(2): 7-13.
Albayati, N. 2011. The Most Medicinal Plants Used in Iraq: Traditional Knowledge. Adv. Environ. Biol., 5(2): 401-406.

Calkins, K.L., Sanchez, L.A., Tseng, C., Faull, K.F., Yoon, A.J., Ryan, C.M., Le, T., and Shew, S.B. 2016. Effect of High- Dose Cysteine Supplementation on Erythrocyte Glutathione: a DoubleBlinded, Randomized Placebo Controlled Pilot Study in Critically Ill Neonates. J. Parenteral and Enteral Nutri., 40(2): 226-234.

Del Bano, M.J., Lorente, J., Castillo, J., Benavente-Garcia, O., del Rio, J.A., Ortuno, A., Quirin, K.W. and Gerard, D. 2003. Phenolic diterpenes, flavones, and rosmarinic acid distribution during the development of leaves, flowers, stems, and roots of Rosmarinus officinalis. Antioxidant activity. $J$. Agri. Food Chem., 51(15): 4247-4253.

Fugh-Berman, A. 2000. Herbs and dietary supplements in the prevention and treatment of cardiovascular disease. Prev. Cardiol., 3(1): 24.

Harborn, J.B. 1984. Phytochemical methods. 2ed (ED.). Chapman and Hall. PP: 288.

Henry, C.L. 2004. Vitamin and Mineral Status: Effects on Physical Performance. Nutri., 20: 632-644.

Iris, F., Benzie, F. and Sissi, W. 2011. Herbal Medicine: Biomolecular and Clinical Aspects, 2nd Edition.

Jahan, N., Rahman, K.U. and Ali, S. 2012. Cardioprotective and antilipidemic potential of Cyperus rotundus in chemically induced cardiotoxicity. Int. J. Agri. Biol., 14: 989-992.

Janina, G., Małgorzata, K. and Aneta, W. 2007. Antioxidative effect of plant extracts and flavones on liposome and erythrocyte membranes. Polish J. Food and Nutri., 57(4): 145-150.

Kalveniene, Z.1., Velziene, S., 
Ramanauskiene, K., Savickas, A., Ivanauskas, L. and Brusokas, V. 2007. The qualitative analysis of ethanol extracts of herbal raw materials by method of high pressure liquid chromatography. Acta Polonia Pharmaceutica, 64(4): 327-333.

Kamboj, V.P. 2000. Herbal medicine, Current Science, Lucknow, India 78: 1. Kandikattu, H.K., Rachitha, P., Krupashree, K., Jayashree, G., Abhishek, V. and Khanum, F. 2015. LC-ESI-MS/MS analysis of total oligomeric flavonoid fraction of Cyperus rotundus and its antioxidant, macromolecule damage protective and antihemolytic effects. Pathophysiol., 22(4) :165-173.

Kumar, K.H., Razack, S., Nallamuthu, I. and Khanum, F. 2014. Phytochemical analysis and biological properties of Cyperus rotundus L. Industrial Crops and Products, 52: 815-826.

Mohanty, J.G., Nagababu, E., Rifkind, J.M. 2014. Red blood cell oxidative stress impairs oxygen delivery and induces red blood cell aging. Frontiers Physiol., 5: 84.

Mot, A.C., Bischin, C., Damian, G. and Silaghi-Dumitrescu, R. 2015. Antioxidant activity evaluation involving hemoglobin-related free radical reactivity. Methods in Mol. Biol., 1208: 247-255.

Munne-Bosch, S. and Alegre, L. 2001. Subcellular Compartmentation of the Diterpene Carnosic Acid and Its Derivatives in the Leaves of Rosemary. Plant Physiol., 125(2): 1094-1102.

Musiychuk, K., Sivalenka, R., Jaje, J., Bi, H., Shaw, B. R., Jones, M., Golovina, T., Schnipper, J., Khandker, L., Sun, R., Li, C., Kang, L., VoskinarianBerse,V., Zhang, X., Streatfield, S. Hambor, J. Abbot, S. and Yusibov, V. 2013. Plant-Produced Human
Recombinant Erythropoietic Growth Factors Support Erythroid Differentiation In Vitro. Stem Cells and Develop., 22(16): 2326- 2340.

Nagababu, E., Scott, A.V., Johnson, D.J., Dwyer, I.M., Lipsitz, J.A., Barodka, V.M., Berkowitz, D.E. and Frank, S.M. 2016. Oxidative stress and rheologic properties of stored red blood cells before and after transfusion to surgical patients. J. Transfusion, 56(5): 1101-1111.

Necib, Y., Bahi, A., Merouane, F., Bouadi, H. and Boulahrouf, K. 2015. Comparative study of a new lectin extracted from roots of plants: Cyperus rotundus, Pistacia lentiscus and Ruta graveolens. World J. Pharmaceutical Res., 4: (1), 1720-1733.

Neuwirt, J. and Ponka, P. 1977. Regulation of Hemoglobin Synthesis. 1ed. Marinus Nijhoff, The Hague. The Netherland, pp: 107.

Oladunni, O.M., Abass, O.O., and Adisa, A.I. 2011. Studies on Physicochemical Properties of the Oil, Minerals and Nutritional Composition of Nut Grass (Cyperus rotundus). American J. Food Technol., 6: 1061-1064.

Rezaie, T., McKercher, S.R., Kosaka, K., Seki, M.,Wheeler, L., Viswanath, V., Chun,T., Joshi, R., Valencia, M., Sasaki, S., Tozawa,T., Satoh,T. and Lipton, S.A. 2012. Protective Effect of Carnosic Acid, a Pro-Electrophilic Compound, in Models of Oxidative Stress and Light-Induced Retinal Degeneration. Investigative Ophthalmol. Visual Sci., 53(12): 78477854.

Sak, K. 2014. Cytotoxicity of dietary flavonoids on different human cancer types. Pharmacognosy Rev., 8(16): 122-146.

Sancheti, G. and Goyal, P.K. 2006. Prevention of radiation induced 
haematological alterations by medicinal plant Rosmarinus officinalis, in rabbits. African J. Traditional, Complementary, Alternative Med., 13: 4(2): 165-172.

Silpa, S., Takreem, A. and Jaya Sekhar,V. L. 2014. Antidiabetic and wound healing activity of stem ethanolic extract of Cyperus rotundus in alloxan induced diabetic rats. Indo American $J$. Pharma. Res., 4(9): 3808-3818.

Steel, R.J.D. and Torrie, J.H.1986. Principles and procedures of statistics: Abiometrical approach. 2nd Ed. Mc Graw Hill Book Company, Inc.
NY.USA.

Vasudevan, D.M. and Sreekumari, S. 2007. Textbook Of Biochemistry For Medical Students. 5th Ed. Jaypee Brothers Ltd. pp: 191-193.

Vikulov, A.D., Osetrov, I.A. and Melnikov, A.A. 2001. Activity of Na, K-ATPase of Erythrocytes in physically Active Subjects. J. Human Physiol., 27(3): 375-377.

Yazdanparast, R. and Ardestani, A. 2007. In vitro antioxidant and free radical scavenging activity of Cyperus rotundus. J. Med. Food, 10(4): 667674.

\section{How to cite this article:}

Sarmad Abdul Razzaq Abood Alsaadi. 2016. Estimation of the Changes in Hematological Standards of Albino Rabbits Treated with Different Concentrations for Alcoholic Extract of Cyperus rotundus (Nutsedge) and Rosmarinus officinalis (Rosemary). Int.J.Curr.Microbiol.App.Sci. 5(7): 759-767. doi: http://dx.doi.org/10.20546/ijcmas.2016.507.087 